\title{
The Distribution and Problems of the Invasive Alien Plant, Mimosa diplotricha C. Wright ex Sauvalle (Mimosaceae) in Nigeria
}

\author{
Frank Ekhator ${ }^{1}$, Osariyekemwen O. Uyi ${ }^{2,3^{*}}$, Celestine E. Ikuenobe ${ }^{1}$, Celestina O. Okeke ${ }^{1}$ \\ ${ }^{1}$ Agronomy Division, Nigerian Institute for Oil Palm Research, Benin City, Nigeria; ${ }^{2}$ Biological Control of Invasive Alien Plant Spe- \\ cies Laboratory, Department of Zoology and Entomology, Rhodes University, Grahamstown, South Africa; ${ }^{3}$ Department of Animal \\ and Environmental Biology, University of Benin, Benin City, Nigeria. \\ Email: *osariyekemwenuyi@yahoo.com
}

Received February $28^{\text {th }}$, 2013; revised March $30^{\text {th }}$, 2013; accepted April $10^{\text {th }}, 2013$

Copyright (C) 2013 Frank Ekhator et al. This is an open access article distributed under the Creative Commons Attribution License, which permits unrestricted use, distribution, and reproduction in any medium, provided the original work is properly cited.

\begin{abstract}
Mimosa diplotricha is an invasive perennial, scrambling, thorny, leguminous shrub of neotropical origin widely acknowledged as a major economic, agricultural and ecological burden in its introduced ranges. Although the plant is thought to have been present in Nigeria for well over two decades, its mode and time of introduction is uncertain. In spite of the continuing spread of, and the menace caused by M. diplotricha in Nigeria, no attempt has been made to map the distribution of the plant countrywide. Therefore, we conducted a countrywide survey between 2007 and 2009, sponsored by the Weed Science Society of Nigeria (WSSN) to determine the spread and status of Mimosa diplotricha in Nigeria. A further objective of this paper was to review literatures on Mimosa diplotricha in Nigeria and elsewhere to enable comparison. In this paper, we report on the spread, distribution and problems of Mimosa diplotricha in Nigeria based on the field monitoring surveys conducted. The distribution of this invasive plant in Nigeria has been mapped and is presented together with its ecology and problems being caused. Since the early 1990s, the weed has started to spread and invade many parts of the country causing significant damage to many natural and semi natural ecosystems. The different control options used by farmers to control Mimosa diplotricha in Nigeria are discussed. Based on the successful control of this invasive plant using the biocontrol agent, Heteropsylla spinulosa in countries such as Australia and Papua New Guinea (PNG), we discussed the biological control prospects for the management of Mimosa diplotricha in Nigeria. Such control attempts stands to benefit from international collaborations between Nigerian institutions and a host of others in Australia, PNG and/or Brazil. Finally three major causes for the massive and continuing spread of this weed in Nigeria are presented with recommendations for the Nigerian government and institutions to: 1) formulate policies and legislations regarding the control and management of invasive alien plant species which is currently nonexistent; 2) enlighten the general public on the dangers of invasive alien plant species such as Mimosa diplotricha; and 3 ) initiate actions such as early detection and rapid response (EDRR) and biological control in order to prevent further spread of, and invasion by invasive plant species including Mimosa diplotricha.
\end{abstract}

Keywords: Mimosa diplotricha; Invasive Weed; Problems; Spread; Control Prospects; Nigeria

\section{Introduction}

Invasion by alien plants constitute a disturbing phenomenon and is a growing problem in many parts of the world including Africa, where they impact negatively on natural and semi natural ecosystems with negative consequences for biodiversity [1,2], agricultural productivity [3,4] and delivery of ecosystem services [5-7]. The increase in human population and urbanization which is

*Corresponding author. often accompanied by unprecedented alteration and modification of ecosystems, and promotion and the expansion of global trade has led to the widespread distribution of large number of species outside of their native ranges. The above reasons have been implicated in the widespread distribution of invasive alien plant species causing significant economic losses [8-10].

Invasive shrubs such as Mimosa diplotricha C. Wright ex Sauvalle (=Mimosa invisa Mart. ex Colla) (Mimosaceae) that impact negatively on existing plant commu- 
nities [11-14] pose a threat to biodiversity, agriculture and human livelihoods. Mimosa diplotricha is a fast growing, annual (short-lived) or perennial shrubby leguminous vine native to the Americas [11,15]. Although, the nativity of the weed has been traced to Brazil $[11,16]$, its natural habitat range in the Americas stretches from southern Mexico to northern Argentina including the Caribbean Islands [12,15]. In its introduce ranges, $M$. diplotricha was first recorded in Java in 1900 [17 cited in 12], while in Australia, the first record of the weed dates back to the 1920s [11]. This leguminous vine has invaded large parts of Asia (India, Sri Lanka, Indonesia, Thailand, Vietnam, Malaysia, the Philippines, China, Cambodia and Taiwan), Africa (Nigeria, Mauritius and Reunion) and several Pacific Islands including Australia and Papua New Guinea (PNG) [12,14,16] forming dense tangled, thorny clumps that smother other vegetation. In Africa, recent reports indicate that $M$. diplotricha is present in Ethiopia [18], Ghana, [19], Malawi [10] and Guinea in West Africa [20 cited in 15]. In these countries and in many others, the weed was reported as Mimosa invisa Mart. ex Colla. In its introduced ranges, M. diplotricha is a serious weed of arable and plantation crops as well as pastoral agriculture and its also easily seen along roadsides, riverbanks and wastelands. For example, Kuniata [14] reported over $80 \% \mathrm{M}$. diplotricha infestation on a large sugarcane farm in Papua New Guinea. Mimosa diplotricha has been described as being among the top ten weeds in countries where it is invasive [21]. Because of the negative attributes of $M$. diplotricha, it has remained a subject of several eradication and/or control programmes in some countries (e.g. Australia and some Pacific Islands) [14,22-24].

Mimosa diplotricha is thought to have been present in Nigeria for well over 2 decades. Following its introduction, it has quickly spread attaining invasive status in the country. In spite of the invasive potentials of, and the menace caused by $M$. diplotricha in Nigeria, not much is known about its distribution, ecology and mechanisms for invasion. Only a few literatures exist on this weed in Nigeria and other parts of West Africa. For example, Akobundu and Agyakwa $[25,26]$ listed the weed as $M$. invisa and describe it as an introduced weed in West Africa. Alabi et al. [13] reported it as a serious pest of cassava in Nigeria, while several literatures have looked at the control options available for the weed [27-30]. In this paper, we report on the spread, distribution and problems of $M$. diplotricha in Nigeria based on field monitoring surveys conducted between 2007 and 2009 sponsored by the Weed Science Society of Nigeria (WSSN). A further objective of this paper was to review literatures on the weed in Nigeria and elsewhere to enable comparison. Finally, we discuss the different control options used by farmers to control M. diplotricha in Nigeria and elsewhere. Because of the environmental friendliness, selfsustainability and cost effectiveness of biological control [31], we discuss its prospects for the control and management of $M$. diplotricha in Nigeria. This paper is expected to raise awareness on the implications of the uncontrolled spread of the weed in Nigeria and in other West African countries without any effective national or regional control programme as was in the case of Chromolaena odorata (L.) King and Robinson (Asteraceae: Eupatorieae) in West Africa [32].

\section{Descriptive Characteristics and Ecology}

Mimosa is one of the largest genera of Mimosoid legumes with approximately 500 species [33-39]. The major centre of diversity for mimosa is central Brazil where many species are found. Although M. diplotricha is native to the Americas, it is thought to have originated from Brazil $[11,16]$. Mimosa diplotricha, also known as the giant sensitive plant is an annual shrubby and scrambling climber that often forms dense thickets and can sometimes behave as a perennial leguminous vine. Several literatures have documented the descriptive biology of $M$. diplotricha [11,12,16,26,40,41]. The stem is four angled, woody decumbent base with re-curved thorns (3 - $6 \mathrm{~mm}$ long), up to 3 metres in height. The main stalk has up to 8 pairs of sub-leaf stalks and each sub-leaf stalk may bear as many as 20 to 30 opposite leaflets, that are small, bright green, alternate, bipinnate and sessile and are about 6 to $12 \mathrm{~mm}$ long and $1.5 \mathrm{~mm}$ wide. The inflorescence is an axiliary or terminal raceme, one to three in the axil of leaves, on hairy stalks which are $1 \mathrm{~cm}$ long, about $12 \mathrm{~mm}$ in diameter. The pale pink corolla is united at least at the base (i.e. gamopetalous). The flower has four petals and eight stamens. The fruit is a spiny, three to four seeded pod borne in clusters. It is linear, flat, 10 to $35 \mathrm{~mm}$ long and splitting transversely into seeded sections, which separate at the grooves. The smooth light brown seed is flat, hard, ovate, and about $2.5 \mathrm{~mm}$ long [16]. Seeds are retained in spiny pod segments and are adapted for dispersal by floating on water as well as by spiny segments adhering to animal fur and clothing. The movement of vehicles and machineries and the transportation of contaminated plants or soil materials can also assist the spread of the seeds. A mature plant may produce viable seeds. Some of these may germinate immediately while others may remain in the soil for several years before germination. The seeds can remain dormant for up to 50 years $[40,41]$. It is a prolific seed producer with seeds ranging from 8000 to 12,000 seeds $/ \mathrm{m}^{2}$ and a single plant can produce up to 10,000 seeds per annum [40], hence spread out rapidly to agricultural lands and lands for other uses [16]. Kuniata and Korowi [42] docu- 
mented the potential of the $M$. diplotricha to produce up to 20,000 seeds $/ \mathrm{m}^{2}$. The plant seems to prefer open areas and disturbed ecosystems such as forest fringes and roadsides with lots of sunlight. In Nigeria, $M$. diplotricha grows vigorously during the wet season (between March and October) and it flowers and fruits between September and November. The plant was observed to begin dehisced mature seeds mainly in late December to early February. Then the plant continues to wither as the fruits ripe and dies in late January-February due to the dry weather. It starts to re-establish itself from seeds in the soil immediately after rains. The ability of the plant to tolerate a wide range of soil $p \mathrm{H}$ has been documented in Nigeria [43]. Our observation showed that the weed can survive in many soil and vegetation types ranging from rainforest to derived savanna (Table 1). The ability of the plant to tolerate different soil types and altitudinal regime has been reported [41,44].

\section{Observations and Distribution}

The earliest literatures on the presence of $M$. diplothrica in Nigeria are those of Akobundu and Agyakwa [25] and Waterhouse and Norris [11]. The weed had only since the 1990s attracted the attention of locals (farmers), agriculturists, ecologists and other stakeholders because of its alarming spread, invasive tendencies and perceived negative impacts on agriculture and livelihoods. In spite of the reports on, and evidences of the spread of M. diplotricha into several parts of Nigeria, the local distribution range of the weed is not known. Earlier publications on the weed only focus on 1) the incidence of spread in particular states or provinces [28,45], and 2) control measures available for the weed (see introduction section). In

Table 1. Vegetation and soil types as well as locations where Mimosa diplotricha is found Nigeria, information on infestation rating is also given.

\begin{tabular}{|c|c|c|c|c|c|}
\hline States & Towns & $\begin{array}{l}\text { Coordinates of } \\
\text { towns }\end{array}$ & $\begin{array}{l}{ }^{*} \text { Level of } \\
\text { infestation }\end{array}$ & Vegetation types & Soil types \\
\hline Abia & Umuahia & $5^{\circ} 32^{\prime} \mathrm{N}^{\circ} 29^{\prime} \mathrm{E}$ & High & Lowland rainforest & Ferrallitic \\
\hline Anambra & Onitsha & $6^{\circ} 11^{\prime} \mathrm{N} 6^{\circ} 43^{\prime} \mathrm{E}$ & High & Deciduous forest & Alluvial/hydromorphic/ferrallitic \\
\hline Akwa-Ibom & Ikotekpene & $5^{\circ} 11^{\prime} \mathrm{N} 7^{\circ} 43^{\prime} \mathrm{E}$ & High & Tropical rainforest & Upland alluvial \\
\hline Bayelsa & Yenagoa & $4^{\circ} 55^{\prime} \mathrm{N} 6^{\circ} 15^{\prime} \mathrm{E}$ & Low & $\begin{array}{l}\text { Mangrove forest/coastal forest/ } \\
\text { fresh water swamps }\end{array}$ & Sedimentary alluvium \\
\hline Cross River & Calabar & $4^{\circ} 57^{\prime} \mathrm{N} 8^{\circ} 19^{\prime} \mathrm{E}$ & Low & Coastal mangrove/rainforest & $\begin{array}{c}\text { Basement complex/ } \\
\text { sedimentary cretaceous sand stone }\end{array}$ \\
\hline Delta & Asaba & $6^{\circ} 16^{\prime} \mathrm{N} 6^{\circ} 34^{\prime} \mathrm{E}$ & High & Mangrove swamp/evergreen forest & $\begin{array}{l}\text { Hydromorphic/ferrallitic/alluvial/ } \\
\text { basement complex }\end{array}$ \\
\hline Ebonyi & Abakaliki & $6^{\circ} 20^{\prime} \mathrm{N} 8^{\circ} 06^{\prime} \mathrm{E}$ & High & Rainforest & Shale parent materials \\
\hline Edo & Benin City & $6^{\circ} 19^{\prime} \mathrm{N} 5^{\circ} 37^{\prime} \mathrm{E}$ & High & Humid rainforest & Basement complex \\
\hline Ekiti & Ado-Ekiti & $7^{\circ} 41^{\prime} \mathrm{N} 5^{\circ} 15^{\prime} \mathrm{E}$ & Low & Lowland forest/derived savanna & Basement complex \\
\hline Enugu & Enugu & $6^{\circ} 27^{\prime} \mathrm{N} 7^{\circ} 30^{\prime} \mathrm{E}$ & High & Rainforest/derived savanna & Shale parent materials \\
\hline Imo & Owerri & $6^{\circ} 29^{\prime} \mathrm{N} 7^{\circ} 01^{\prime} \mathrm{E}$ & Low & Rainforest & Coastal plain sand \\
\hline Kogi & Okene & $7^{\circ} 33^{\prime} \mathrm{N} 6^{\circ} 13^{\prime} \mathrm{E}$ & Low & Derived savanna & Sedimentary rock/alluvium/ferrasols \\
\hline Lagos & Lagos & $6^{\circ} 27^{\prime} \mathrm{N} 3^{\circ} 23^{\prime} \mathrm{E}$ & Low & $\begin{array}{l}\text { Swamp forest/lowland rainforest/ } \\
\text { mangrove forest }\end{array}$ & $\begin{array}{l}\text { Ferrallitic/flavormarine alluvium/ } \\
\text { hydromorphic }\end{array}$ \\
\hline Ogun & Abeokuta & $7^{\circ} 09^{\prime} \mathrm{N} 3^{\circ} 20^{\prime} \mathrm{E}$ & High & Lowland forest/derived savanna & Basement complex \\
\hline Ondo & Akure & $7^{\circ} 15^{\prime} \mathrm{N} 5^{\circ} 111^{\prime} \mathrm{E}$ & High & High rainforest & Basement complex \\
\hline Osun & Ile-Ife & $7^{\circ} 28^{\prime} \mathrm{N} 4^{\circ} 23^{\prime} \mathrm{E}$ & High & Secondary forest/derived savanna & Ferruginous/basement complex \\
\hline Оyо & Ibadan & $7^{\circ} 23^{\prime} \mathrm{N} 3^{\circ} 54^{\prime} \mathrm{E}$ & High & Rainforest/derived savanna & Basement complex/coastal deposit \\
\hline River & Port-Harcourt & $4^{\circ} 47^{\prime} \mathrm{N} 7^{\circ} 00^{\prime} \mathrm{E}$ & Low & Rainforest/fresh water \& mangrove forest & $\begin{array}{l}\text { Marine/fluvial/alluvial/ } \\
\text { fresh water brown loam/sandy soil }\end{array}$ \\
\hline
\end{tabular}

*Infestation rating: High = at least one observed colony greater than 1 hectare. Low = one observed colonies less than 1 hectare. Sources of vegetation and soil type information: states ministry of Agriculture. 
view of the paucity of information on its distribution we conducted informal reconnaissance surveys between May 2007 and October 2009 by travelling through major cities to find M. diplotricha infestations. Also, some questions with respect to its spreading pattern were asked from local farmers in areas where infestation was found, and this was used to map the distribution of the weed and also to examine its status in the country. Mimosa diplotricha infestations were rated as 1) high and 2) low (Table 1, Figure 1). In high infestations, infestation in one observed colony was greater than one hectare, while in low infestations; one observed colony was less than one hectare. The soil types in the locations where the plant was found were obtained from existing soil literatures at the respective state ministries of Agriculture.

The results of the reconnaissance survey showed that M. diplotricha is widely present in the entire southwestern (Ekiti, Lagos, Ogun, Ondo, Osun and Oyo States), southeastern (Abia, Anambra, Enugu, Ebonyi, Imo, Cross River, River and Akwa-Ibom States) and midwestern (Balyelsa, Delta and Edo States) regions of the country (Table 1 and Figure 1). The plant was also recorded in Kogi State (north-central Nigeria, derived savanna). The degree of infestation varied from one state to another. Five states in the southeastern (Anambra, Abia, Ebonyi, Enugu and Akwa-Ibom States), 4 in southwestern (Ogun, Ondo, Osun and Oyo States) and 2 in the mid-western (Edo and Delta States) regions are severely infested by $M$. diplotricha. In these states, the least distance between one colony and another was less than 10 $\mathrm{km}$ with some observed colonies well over 2 hectares. The weed thrived well in different vegetation zones including rainforest and woodland savanna and on different soils varying from the basement complex to sedimentary alluvium, ferrallitic and coastal plain sand (see Table 1). The presence of the weed in the different climatic (see Table 2) and vegetation zones in Nigeria from the coastal forests through humid forests to the derived savanna (woodland savanna) is an indication of the invasive ability of $M$. diplotricha in diverse ecological zones of country. During the survey, M. diplotricha infestations were recorded in arable croplands, plantation crop farms, fallow lands, roadsides, abandoned lands and deforested areas (Figures 2(a)-(e)). This is similar to reports from Burundi, Ethiopia, southwestern Nigeria, Australia, Papua New Guinea and elsewhere, where the weed invades disturbed ecosystems [10,12-14,18]. The frequent destruction of forest for various purposes and the continuous construction of roads and expansion of settlements in Nigeria contribute to the continuous spread of $M$. diplotricha in the country. The invasive success may have also been facilitated by its numerous dispersal methods (e.g. animal grazing, water erosion or flooding and movement of vehicles and transportation of contaminated plant and soil materials). The frequent burning of bushes during the dry season (November to March) for animal hunting and burning during pre-planting operations (e.g. burning after land clearings to remove debris, which is a widely practiced agricultural system in West Africa) also facilitate the spread, germination and growth of $M$. diplotricha in Nigeria. This view was corroborated by most farmers interviewed during our survey. The rapid spread of the weed into agronomic fields in the rainforest zone as well as the spread of the weed into the derived savanna zones (e.g. Okene, in Kogi State) with lower rainfall and higher temperatures suggests that $M$. diplotricha is yet to achieve its full invasive potentials in the country. It appears that both the altitudinal and climatic regimes in the country can support the growth of the weed.

\section{Problems of Mimosa diplotricha}

Although, M. diplotricha has been found in Nigeria for more than 2 decades, it only recently became a serious pest of agriculture, conservation and residential areas $[26,28]$. During our survey, its infestations were recorded in okra, maize, cassava and plantain farms and oil palm and coconut plantations indicating that the weed is not crop specific and could be problematic in any crop systems. This weed species has a significant economic impact on agro-ecosystems in Nigeria including smothering of crops which reduces crop growth and development. For example Alabi et al. [13] studied the interference of M. diplotricha in cassava farms in southwestern Nigeria. The authors showed that, 12 months after interference of the weed, cassava growth parameters were negatively affected. High population of the weed was shown to reduce storage root yield in cassava 12 months after planting. They also reported that yield reduction increased with increased density of the weed. Furthermore, 85\% reduction in crop yield was noticed in a farm infested with natural populations of the weed. Cassava is the most widely grown staple crop in Nigeria [46] providing the main staple for most Nigerians especially the resource poor farmers and rural populations. Because cassava is susceptible to weed interference during the first 10 to 16 weeks after planting $[47,48]$, due to low canopy development for ground cover and weed suppression, farmers in Nigeria are seriously apprehensive about the continuous spread of, and damage caused by M. diplotricha to their crops and livelihood security. The weed has been reported as a very serious pest of oil palm and coconut especially at the nursery stage in Nigeria [43]. Usually oil palm growth in the nursery and field is slow and canopy effects at its early stage of growth on weeds are 


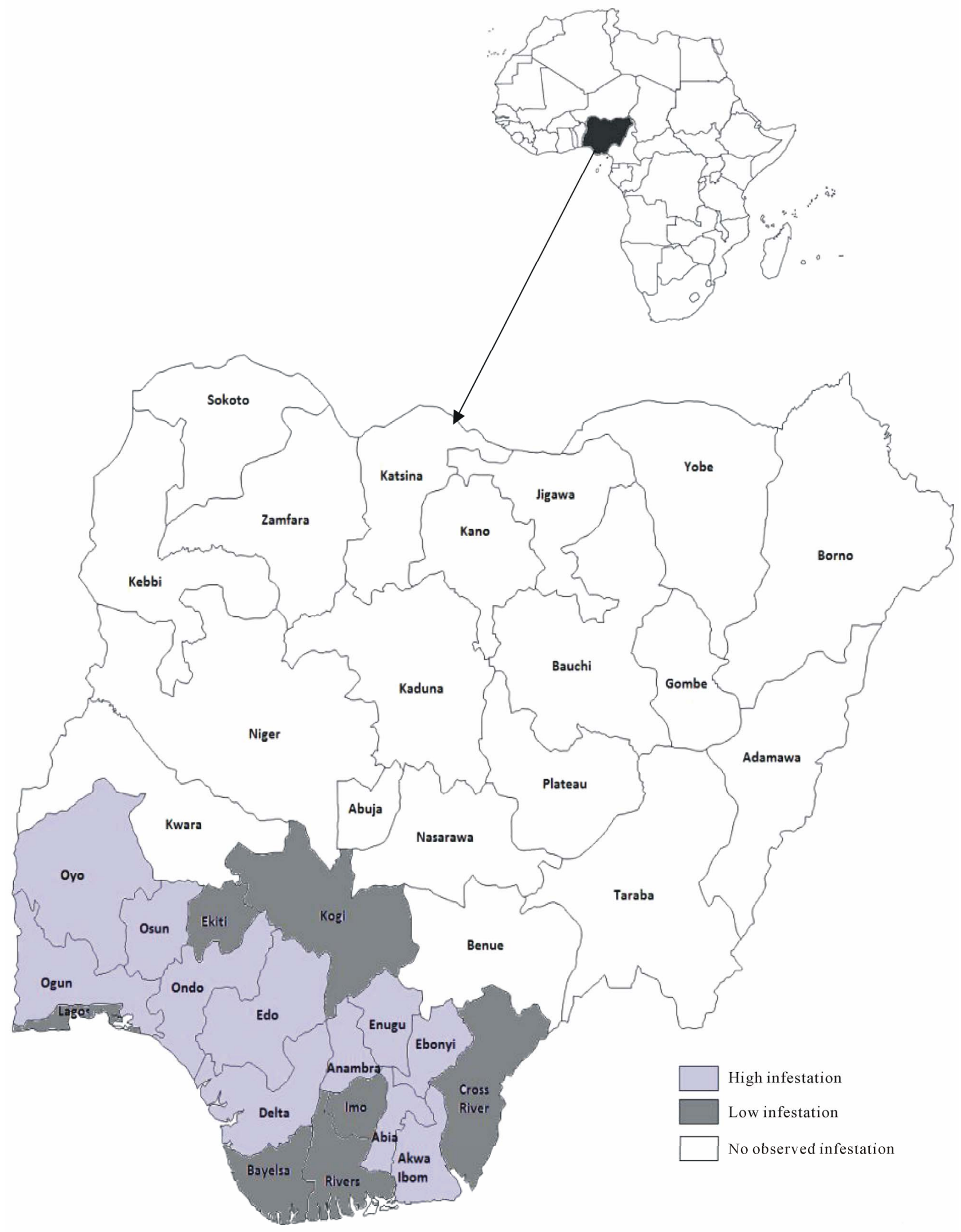

Figure 1. Distribution and infestation levels of Mimosa diplotricha in Nigeria. 
C. Wright ex Sauvalle (Mimosaceae) in Nigeria

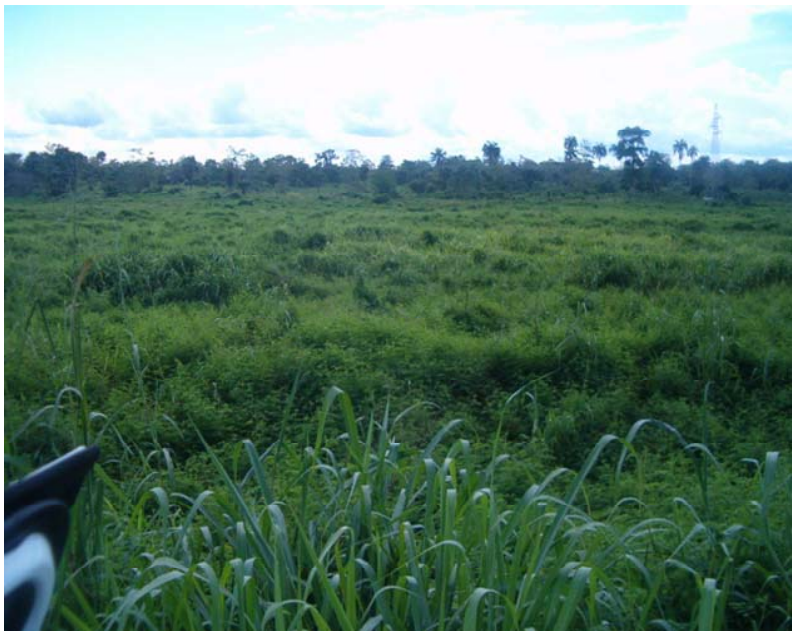

(a)

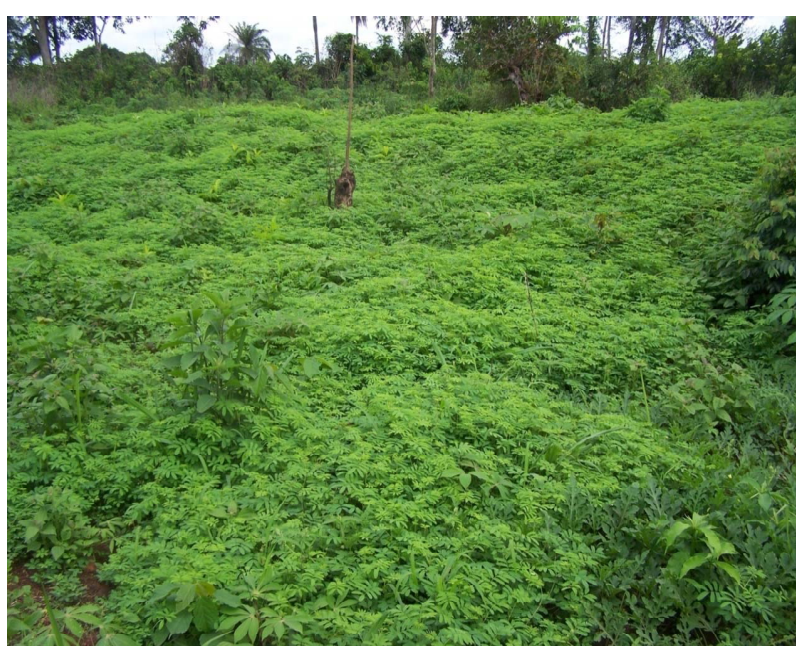

(c)

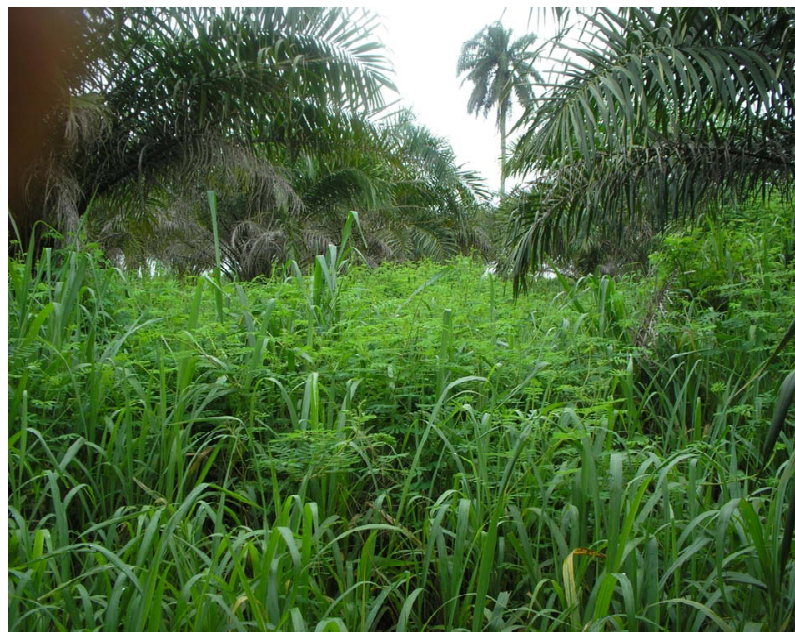

(b)

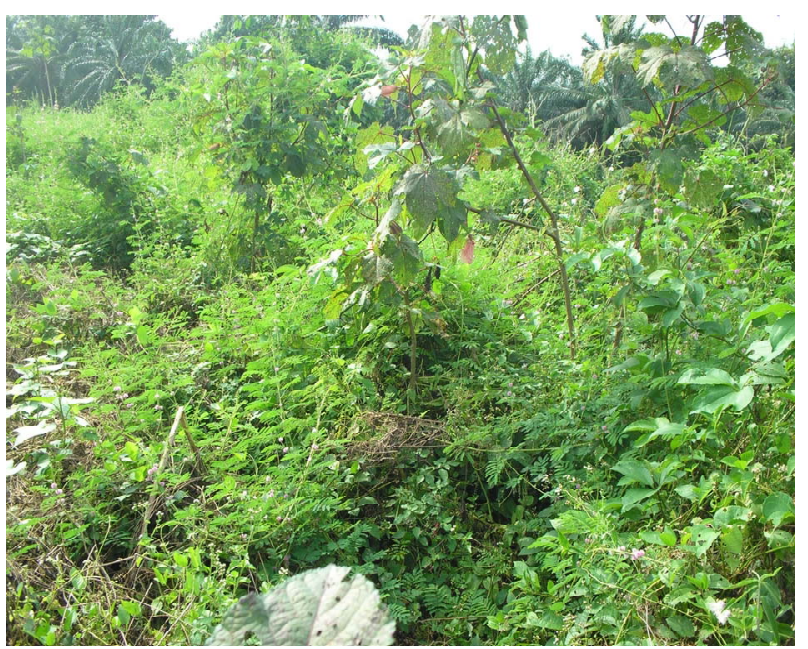

(d)

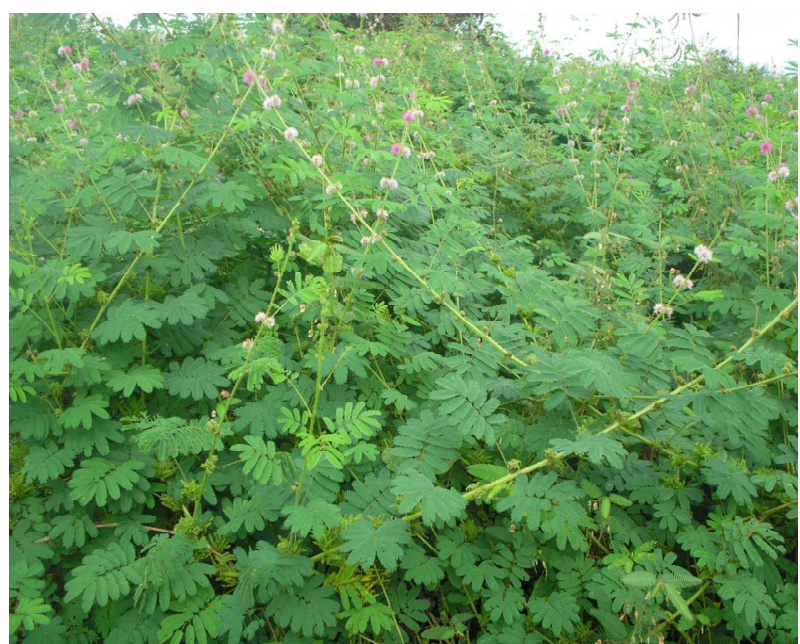

(e)

Figure 2. (a) Mimosa diplotricha infested field in Ondo State, Nigeria; (b) Infestation of oil palm field by Mimosa diplotricha in Benin City, Edo State, Nigeria; (c) Infestation of cassava field by Mimosa diplotricha at Ekpoma, Edo State, Nigeria; (d) Okra field infested by Mimosa diplotricha at Umudike, Abia State, Nigeria; (e) Colony of Mimosa diplotricha at a fallow farm land at Ile-Ife, Osun State, Nigeria. 
Table 2. Climatic range in states (provinces) infested with Mimosa diplotricha.

\begin{tabular}{|c|c|c|c|c|c|c|}
\hline \multirow{2}{*}{ State } & \multicolumn{2}{|c|}{ Rainfall (mm) } & \multicolumn{2}{|c|}{ Temperature $\left({ }^{\circ} \mathrm{C}\right)$} & \multicolumn{2}{|c|}{ Relative humidity } \\
\hline & Mean minimum & Mean maximum & Mean minimum & Mean maximum & @1500 GMT & @0900 GMT \\
\hline Abia & 1780 & 2200 & 21 & 30 & 68 & 75 \\
\hline Anambra & 1704 & 2089.4 & 23.2 & 33.7 & 43 & 68 \\
\hline Akwa Ibom & 2300 & 3500 & 23 & 31 & 69 & 82 \\
\hline Bayelsa & 2800 & 3700 & 23.4 & 29.4 & 68 & 83 \\
\hline Cross River & 3000 & 4200 & 22 & 31.5 & 66 & 80 \\
\hline Delta & 1709.4 & 2890 & 22.3 & 31.5 & 63 & 81 \\
\hline Ebonyi & 1500 & 2000 & 23 & 32 & 64 & 79.4 \\
\hline Edo & 1500 & 2500 & 23.6 & 31.4 & 68 & 81 \\
\hline Ekiti & 1600 & 1800 & 24.3 & 33 & 65 & 79 \\
\hline Enugu & 1721 & 2196.4 & 20.3 & 32.2 & 59 & 70 \\
\hline Imo & 1777.2 & 2916 & 24.5 & 33.5 & 76 & 81 \\
\hline Kogi & 1016 & 1524 & 22.8 & 37 & 51 & 75 \\
\hline Lagos & 1700 & 2800 & 24.2 & 33 & 70 & 84 \\
\hline Ogun & 1050 & 1280 & 22 & 33.1 & 62 & 73 \\
\hline Ondo & 1800 & 2000 & 22.7 & 31.6 & 65 & 80 \\
\hline Osun & 1129.2 & 1770 & 22.1 & 31.9 & 58 & 81 \\
\hline Оуо & 1150 & 1800 & 24 & 31.9 & 61 & 79 \\
\hline River & 2800 & 3500 & 21 & 33 & 72 & 83 \\
\hline
\end{tabular}

minimal, thus this creates a conducive environment for the growth of weeds including $M$. diplotricha. Although, the direct impact of $M$. diplotricha on oil palm and coconut has not been quantified, it is believed that M. diplotricha has the ability to slow the growth and development of the crop and this can prolong expected yield time and reduce yield quality thus posing some serious economic dangers to farmers and plantation owners. Some crops such as maize that are planted at high cropping intensity can create an unsuitable environment for $M$. diplotricha. Although it is difficult to estimate the economic losses due to the weed infestation as well as cost of control of $M$. diplotricha countrywide, Kuniata [14] reported that more than $80 \%$ of sugarcane fields were infested by M. diplotricha in Papua New Guinea. Abandonment of farms planted with cassava, sweet potatoes and bananas have been reported in Papua New Guinea [14]. During our survey, we found some abandoned cassava and maize fields due to infestation of $M$. diplotricha. Mimosa diplotricha has long been recognized as a serious weed of crops in the Pacific Islands, Asia and some African countries were it causes serious problems in coconut, oil palms, tea and rubber plantations, sugarcane and pineapple fields, croplands (cassava, tomatoes, upland rice, soybeans, maize and peanuts) and pasturelands $[11,12,14]$. The prickly thorns of $M$. diplotricha makes weeding of infested farms and harvesting of crops very difficult, hence invasion always leads to increase production and management cost as well as decreased productivity (reduce yield and loss of crops). Many farmers usually avoid lands infested by M. diplotricha.

With respect to biodiversity, infestations by $M$. diplotricha have been reported to hinder the regeneration, reproduction and growth of native species in all infested areas and consequently result in gradual loss of biodiversity [44]. Mimosa diplotricha forms dense single stands in many locations in Nigeria which actively compete with indigenous and non-native species such as $C$. odorata, Panicum maximum Jacq. (Poaceae) and Tithonia diversifolia (Hemsl.) A. Gray (Asteraceae). It scrambles vigorously over other plants forming dense tangled thicket up to $2 \mathrm{~m}$ high and which has the ability to smother and kill other native plants. In India, M. diplotricha smothers other invasive weeds such $C$. odorata and Mikania micrantha H.B.K. (Asteraceae) and establishes itself over them [49]. The potentials of invasive 
plants to cause or threaten native biodiversity and impact negatively on ecosystem services have been recognized $[6,7,31,50]$, as it has been shown that invasive species tends to have high population growth rates, lower level of herbivore damage, high shoot/root ratio and higher plasticity in many functional traits than native species or non-invasive species [51-56]. In Papua New Guinea, $M$. diplotricha causes erosion of endemic species such as Imperata cylindrica (L.) Beauv. (Poaceae) used for thatching roofs in remote villages [14]. The tangled and thorny growth of $M$. diplotricha was observed to reduce foliage quality and quantity in grazing areas and hinders penetration by livestock and humans. The weed also hampers movements of wild animals consequently preventing access to food and other resources. For example, the movement of rhinoceros (Rhinoceros unicornis), Asian elephant (Elephas maximus), tiger (Panthera tigris) and swamp deer (Cervus duvauceli) has been reported to be hampered by dense stands of $M$. diplotricha in Kaziranga National Park in northeast India [44]. The avoidance of the weed by livestock during grazing have been attributed to its sharp and curve thorns and the presence of mimosin (a non-protein amino acid) which is toxic to herbivores if ingested as it can cause vascular endothelial damage, necrosis of heart and liver, and anaemia in cattle [44]. The plant is also known to be an alternative host of nematodes [57, cited in 18].

Although most farmers reckon $M$. diplotricha to be a menace, others perceived it to have some beneficial attributes. They perceive that soil fertility and porosity were better in lands cleared from M. diplotricha. Reports from literature suggest that the weed is a nitrogen $(\mathrm{N})$ fixer [12]. The nitrogen fixed in maize and cabbage when M. diplotricha was left to grow with them, was estimated at about $114 \mathrm{~kg} \cdot \mathrm{N} / \mathrm{ha}$ [58]. Rerkasem [59] suggested that M. diplotricha can be used to build soil fertility in highly degraded lands and forests in Thailand.

\section{Control Options}

Although, biologist, ecologists, conservationists, agriculturists and non-professionals disagree on the best way to respond to, manage and control invasive species [9,31, 60-69], several control options exist for their control and management such as mechanical, chemical and biological control. Early detection and rapid response has been recommended as a best management practice for controlling and/or eradicating new biological invasions $[60,70]$. In this section, we discuss the various control options available for the control of $M$. diplotricha in Nigeria.

\section{Mechanical Control}

Mechanical control of M. diplotricha such as hand re- moval, hoeing, slashing can be effective but difficult due to the presence of sharp thorns on the stems of the plant which are injurious. Alabi et al. [71] studied different weeding regimes for thorny Mimosa control in cassava fields in southwestern Nigeria, and they showed that cassava vegetative growth recovered from $M$. diplotricha interference when the first weeding occurred within 5 weeks after planting but interference for more than that period reduced cassava root yield. The authors also showed that manual removal of the weed at 4, 7 and 11 weeks after cassava planting consistently resulted in higher yield. Due to the regenerative ability of the weed from cut stumps, slashing alone would be ineffective, hence we recommend uprooting as the best mechanical control option. Apart from the popularity of the manual removal methods among Nigeria farmers due to its effectiveness and ease of labour availability (within farmer's family), this method can be very slow, full of drudgery, laborious (takes up 50\% of farmer's time) and it's not practical in large scale farming systems and in marginal lands. There are also reports in literatures, which indicate that manual weeding is unsuitable where farm size is larger than 1.5 hectares because of the difficulty in maintaining the labour force to keep large hectare of crops manually weeded [72]. The effectiveness of this method also depends on timely availability of labour and weather conditions, especially rainfall. Consequently, this method only provides short-term control of the weed and is not long lasting.

\section{Chemical Control}

A number of herbicides such as isoxaflutole (balanced), atrazine, diuron, paraquat, etc. (applied singly or as a mixture) have been recommended for the control of $M$. diplotricha [14,27,28,30,44,73]. In the Pacific Islands, paraquat + diuron applied postemergence has provided good control of $M$. diplotricha and 2,4-D + atrazine has been applied as an overall spray especially in pasture situations to control young to semi-matured stands [73]. In Nigeria, Alabi et al. [28] reported that atrazine + metolachor, bentazon + propanil and acetochlor + atrazine controlled $M$. diplotricha satisfactorily but reduced the yield of cassava compared to hand weeded control. While it is generally advisable to apply herbicides before the onset of flowering and fruiting, repeated applications may be required depending on type of crops and the efficacy of the herbicides. Melifonwu et al. [30] showed that the application of primextra (a formulated mixture of atrazine and metolachlor) followed by hand weeding were able to achieve considerable control of the weed in cassava fields in southeastern Nigeria. Chemical control seems to be the most effective control for M. diplotricha in large scale farming systems because it is less labour 
intensive. However, these chemicals only remain active for a few months and are sometimes too expensive for small holders. Besides being expensive and not environmental friendly, the use of chemical control is not practicable in marginal lands and under invasive conditions, therefore, its use is not sustainable. A combination of several weed control methods such as chemical, mechanical and biological control could be more effective.

\section{Biological Control Prospects}

The use of conventional control methods to control $M$. diplotricha in Nigeria has not checked its continued invasion of new lands. Biological control does not only provide sustainable weed control, but it is also safe to man and the environment. Mimosa diplotricha has long been managed by biological control in Australia and several Pacific Islands with some level of success $[12,14]$. The commencement of a biological control programme for the management of $M$. diplotricha in Australia in the mid 1980s led to the identification of over 70 insect species and 2 fungus species in Brazil as possible biological control agents. Full list of the identified species are listed in Waterhouse [12]. Only 3 insect species out of the over 70 listed proved to be promising biological control candidates. Following several releases in Australia in 1987, the coreid bug, Scamurius sp. (Hemiptera: Coreidae) failed to established [74]. However, another species the psylilid, Heteropsylla spinulosa Muddiman, Hodkinson and Hollis (Hemiptera: Psylloideae) established in Australia following its release in 1987 [22]. Within 2 years of commencing field releases, the tiny sap sucking bug widely dispersed and caused severe damage to M. diplotricha. Feeding damage by this bug resulted in dense clumps of the weed reduced to small masses of bare stems with stunted growth tips that allowed other plant species to re-established [24]. Heteropsylla spinulosa has been shown to cause a reduction of $85 \%$ to $100 \%$ seed production annually [24]. This biocontrol agent also established in Papua New Guinea and had spectacular control over M. diplotricha [42]. This insect has also been released and established in several Pacific Islands [14]. This biocontrol agent should be considered for the control and management of $M$. diploricha in Nigeria because of its ability to cause severe stunting and distortion of leaves and growing tips. Such control attempts could benefit from international collaborations between Nigerian institutions and a host of others in Australia, Papua New Guinea or Brazil. Although extreme weather conditions (e.g. prolonged dry seasons) have been found to reduce the abundance and effectiveness of $H$. spinulosa, this is highly unlikely in southern Nigeria because of the high rainfall experienced there, and the high humidity levels all year round. The climate in southern Nigeria is likely to favour the establishment and performance of $H$. spinulosa most because of the high rainfall and fairly stable temperatures all year round. Kuniata and Korowi [42] discussed strategies of preserving psyllids during dry seasons such as application of nitrogen to plants, culturing of the insects in irrigated plots and making releases when the weed is actively growing. The third promising candidate is Psigida walkeri (Grote) (Lepidoptera: Citheroniidae), a native of Brazil. The larvae of the moth can cause considerable damage by feeding on leaves, tender stems, flower buds and tender seed pods of $M$. diplotricha [75]. Although, attack by $P$. walkeri can prevent flowering and seed production, the agent was not released in Australia because it fed on Acacia and Neptunia plants [14]. We recommend that $H$. spinulosa should be prioritized alongside $P$. walkeri in Nigeria. Host specificity testing of the 2 agents should be conducted before releases are made.

\section{Conclusion}

Since the introduction of $M$. diplotricha into Nigeria a few decades ago, the weed has extensively spread to infest large parts in the south and small parts of the north. Apart from the invasive characteristics of the M. diplotricha itself, its invasion success and continuous spread have been due to: 1) the lack of natural enemies controlling it; 2) the increased human disturbances such as deforestation, bush burning, road construction and expansion of human settlements associated with recent economic growth and development; and 3) the lack of a coordinated control and management approach by government agencies and other institutions of state. The Federal Government of Nigeria should take the lead in the control and management of invasive alien plant species in the country, as government's participation and interest would help to: 1) formulate policies and legislations regarding the control and management of invasive alien plant species which is currently nonexistent; and 2) enlighten the general public on the implications of biological invasions. In the meantime, we recommend that the local governments and other concerned authorities should initiate actions such as early detection and rapid response (EDRR) $[60,70,76]$ to prevent further spread of, and invasion by the weed. Government and institutions in Nigeria should share knowledge and experiences on the management of $M$. diplotricha and aspects of its ecology with countries such as Australia, Papua New Guinea, India and Thailand that are also affected by the weed. Furthermore, international cooperation and communication with countries such as Australia and Papua New Guinea which have successfully controlled the weed using biological control is critical to the successful management and control of $M$. diplotricha in Nigeria. 


\section{REFERENCES}

[1] R. N. Mack, D. Simberloff, M. W. Lonsdale, H. Evans, M. Clout and F. A. Bazzaz, "Biotic Invasions: Causes, Epidemiology, Global Consequences, and Control,” Ecological Applications, Vol. 10, No. 3, 2000, pp. 689-710. doi:10.1890/1051-0761(2000)010[0689:BICEGC]2.0.C $\underline{\mathrm{O} ; 2}$

[2] M. Rejmánek, D. M. Richardson, S. I. Higgins, M. Pitcairn and E. Grotkopp, "Ecology of Invasive Plants: State of the Art,” In: H. A. Mooney, J. A. McNeely, L. Neville, P. J. Schei and J. Waage, Eds., Invasive Alien Species: A New Synthesis, Island Press, Washington DC, 2005, pp. 104-162.

[3] D. Pimentel, R. Zuniga and D. Morrison, "Update on the Environmental and Economic Costs Associated with Alien-Invasive Species in the United States,” Ecological Economics, Vol. 52, No. 3, 2005, pp. 273-288. doi:10.1016/j.ecolecon.2004.10.002

[4] F. Williams, R. Eschen, A. Harris, D. Djeddour, C. Pratt, R. S. Shaw, S. Varia, J. Lamontagne-Godwin, S. E. Thomas and S. T. Murphy, "The Economic Cost of Invasive Non-Native Species on Great Britain,” CABI, Wallingford, 2010.

[5] H. A. Mooney, "Invasive Alien Species: The Nature of the Problem,” In: H. A. Mooney, R. N. Mack, J. A. McNeely, L. E. Neville, P. J. Schei and J. K. Waage, Eds., Invasive Alien Species: A New Synthesis, Island Press, Washington DC, 2005, pp. 1-15.

[6] L. Pejchar and H. A. Mooney, "Invasive Species, Ecosystem Services and Human Well-Being," Trends in Ecology and Evolution, Vol. 24, No. 9, 2009, pp. 497-504. doi:10.1016/j.tree.2009.03.016

[7] M. Vilá, J. L. Espinar, M. Hejda, P. E. Hulme, V. Jarošík, J. L. Maron, J. Pergl, U. Schaffner, Y. Sun and P. Pyšek, "Ecological Impacts of Invasive Alien Plants: A MetaAnalysis of Their Effects on Species, Communities and Ecosystems,” Ecology Letters, Vol. 14, No. 7, 2011, pp. 702-708. doi:10.1111/j.1461-0248.2011.01628.x

[8] D. Pimentel, "Biological Invasions: Economic and Environmental Costs of Alien Plant, Animal and Microbe Species,” CRC Press, Boca Raton, 2002. doi:10.1201/9781420041668

[9] C. Perrings, H. A. Mooney and M. Williamson, "Bioinvasions and Globalization,” Oxford University Press, Oxford, 2010.

[10] J. Bigirimana, J. Bogaert, C. De Canniere, J. Lejoly and I. Parmentier, "Alien Plant Species Dominate the Vegetation in a City of Sub-Saharan Africa," Landscape and Urban Planning, Vol. 100, No. 3, 2011, pp. 251-267. doi:10.1016/j.landurbplan.2010.12.012

[11] D. F. Waterhouse and K. R. Norris, "Biological Control-Pacific Prospects,” Inkata Press, Melbourne, 1987.

[12] D. F. Waterhouse, "Biological Control of Weeds: Southeast Asia prospects,” Australian Center for International Agricultural Research, Canberra, 1994.

[13] B. S. Alabi, A. O. Ayeni, A. A. Agboola and B. A. Majek, "Giant Sensitive Plant Interference in Cassava," Weed
Science, Vol. 49, No. 2, 2001, pp. 171-176. doi:10.1614/0043-1745(2001)049[0171:GSIIC]2.0.CO;2

[14] L. S. Kuniata, "Mimosa diplotricha C. Wright ex Sauvalle (Mimosaceae),” In: R. Muniappan, G. V. P. Reddy and A. Raman, Eds., Biological Control of Tropical Weeds Using Arthropods, Cambridge University Press, Cambridge, 2009, pp. 247-255. doi:10.1017/CBO9780511576348.013

[15] M. F. Simon and C. Proença, "Phytogeographic Patterns of Mimosa (Mimosoideae, Leguminosae) in the Cerrado biome of Brazil: An Indicator Genus of High-Altitude Centers of Endemism?” Biological Conservation, Vol. 96, No. 3, 2000, pp. 279-296. doi:10.1016/S0006-3207(00)00085-9

[16] L. G. Holm, D. L. Plucknett, J. V. Pancho and J. P. Herberger, "The World's Worst Weeds: Distribution and Biology,” University Press, Hawaii, 1977.

[17] M. Soerjani, A. J. G. Kostermans and G. Tjitrosoepomo, "Weeds of Rice in Indonesia,” Balai, Pustaka, 1987.

[18] M. Wakjira, “An Invasive Alien Weed Giant Sensitive Plant (Mimosa diplotricha Sauvalle) Invading Southwestern Ethiopia," African Journal of Agricultural Research, Vol. 6, No. 1, 2011, pp. 127-131.

[19] A. K. Anning and K. Yeboah-Gyan, "Diversity and Distribution of Invasive Weeds in Ashanti Region, Ghana," African Journal of Ecology, Vol. 45, No. 3, 2007, pp. 355-360. doi:10.1111/j.1365-2028.2007.00719.x

[20] S. Lisowski, "The Mimosaceae in the Flora of Guinea (Western Africa),” Fragmenta Floristicaet Geobotanica, Vol. 41, No. 1, 1996, pp. 339-354.

[21] D. F. Waterhouse, “The Major Invertebrate Pests and Weeds of Agriculture and Plantation Forestry in Southern and Western Pacific,” Monograph 44, ACIAR, Canberra, 1997.

[22] B. W. Willson and C. A. Garcia, "Host Specificity and Biology of Heteropsylla spinulosa (Hom: Psyllidae) Introduced into Australia and Western Samoa for the Biological Control of Mimosa invisa,” Entomophaga, Vol. 37, No. 2, 1992, pp. 293-299. doi:10.1007/BF02372430

[23] L. S. Kuniata, "Importation and Establishment of Heteropsylla spinulosa (Homoptera: Psyllidae) for the Biological Control of Mimosa invisa in Papua New Guinea," International Journal of Pest Management, Vol. 40, No. 1, 1994, pp. 64-65. doi:10.1080/09670879409371855

[24] M. P. Ablin, "Growth and Reproduction of the Weed, Mimosa invisa, in Northeast Queensland after the Introduction of the Biocontrol Agent Heteropsylla spinulosa," M.Sc. Thesis, James Cook University, Townsville, 1995.

[25] I. O. Akobundu and C. W. Agyakwa, "A Handbook of West African Weeds,” International Institute of Tropical Agriculture, Ibadan, 1987.

[26] I. O. Akobundu and C. W. Agyakwa, "A Handbook of West African Weeds,” 2nd Edition, International Institute of Tropical Agriculture, Ibadan, 1998.

[27] A. A. Melifonwu, "Control of Mimosa inivisa in Maize (Zea mays) with Atrazine and Its Mixtures with Alachlor and Metolachlor,” Nigerian Journal of Weed Science, Vol. 
7, 1994, pp. 9-14.

[28] B. S. Alabi, A. O. Ayeni and A. A. Agboola, "Effect of Selected Herbicides on the Control of Thorny Mimosa in Cassava,” Nigerian Journal of Weed Science, Vol. 12, 1999, pp. 51-57.

[29] F. Ekeleme and C. I. Ekwenta, "Effect of Tillage and Soil Applied Herbicides on Mimosa invisa (Mart) Control in a Humid Tropical Environment,” Nigeria Agricultural Journal, Vol. 35, 2004, pp. 68-75.

[30] A. A. Melifonwu, D. S. Korieocha, M. C. Ogbonna and R. B. Balogun, "Effect of Selected Herbicides and Integrated Weed Management on the Control of Mimosa invisa Mart incassava (Manihot esculenta Crantz)," International Journal of Applied Research and Technology, Vol. 1, No. 2, 2012, pp. 187-196.

[31] T. W. Culliney, "Benefits of Classical Biological Control for Managing Invasive Plants," Critical Reviews in Plant Sciences, Vol. 24, No. 2, 2005, pp. 131-150. doi:10.1080/07352680590961649

[32] O. O. Uyi and I. B. Igbinosa, "Status of Chromolaena odorata and Its Biocontrol in West Africa,” In: C. Zachariades, R. Muniappan, L. Strathie and M. Day, Eds., Proceedings of the 8th International Workshop on Biological Control and Management of Chromolaena odorata, Nairobi, 1-5 November 2010, in Press.

[33] J. F. Villiers, "New Mimosa spp. L. from Madagascar (Leguminosae, Mimosoideae)," Bulletin du Museum National d'Histoire Naturelle Section B Adansonia Botanique Phytochimie, Vol. 12, 1990, pp. 227-232.

[34] R. C. Barneby, "Sensitivae Censitae: A Description of the Genus Mimosa Linnaeus (Mimosaceae) in the New World," Memoirs of the New York Botanical Garden, Vol. 65, 1991, p. 835.

[35] R. C. Barneby, "Increments to the Genus Mimosa (Mimosaceae) from South America,” Brittonia, Vol. 45, No. 4, 1993, pp. 328-332. doi:10.2307/2807606

[36] R. C. Barneby, "Towards a Census of Genus Mimosa (Mimosaceae) in the Americas: A New Species from Mexico (Baja California Sur) and Two from Planaltine Brazil,” Brittonia, Vol. 49, No. 4, 1997, pp. 452-457. doi:10.2307/2807733

[37] M. K. Alam and M. Yusof, "The Genus Mimosa Linn. from Bangladesh,” Bangladesh Journal of Botany, Vol. 21, No. 1, 1992, pp. 53-58.

[38] R. Grether and A. Martinez-Bernal, “Mimosa tjuplilcana, a New Species of Series Plurijugae (Leguminosae) from the State of Mexico, Mexico,” Systematic Botany, Vol. 21, No. 4, 1996, pp. 617-621.doi:10.2307/2419619

[39] R. Grether, S. Camargo-Ricalde and A. Martõ ÂnezBernal, "Especies del GeÂnero Mimosa (Leguminosae) Presentes en MeÂxico.Boletin de la Sociedad,” Botanica de Mexico, Vol. 58, 1996, pp. 149-152.

[40] W. T. Parsons and E. G. Cuthbertson, "Noxious Weeds of Australia,” Inkata Press, Melbourne, 1992.

[41] B. S. Chauhan and D. E. Johnson, "Seed Germination and Seedling Emergence of Giant Sensitive Plant (Mimosa invisa)," Weed Science, Vol. 56, No. 2, 2008, pp. 244-248.
doi:10.1614/WS-07-120.1

[42] L. S. Kuniata and K. T. Korowi, "Bugs Offer Sustainable Control of Mimosa invisa and Sida spp. in the Markham Valley, Papua New Guinea,” In: J. M. Cullen, D. T. Briese, D. J. Kriticos, M. W. Lonsdale, L. Morin and J. K. Scott, Eds., Proceedings of the 14th International Symposium on Biological Control of Weeds, Canberra, 27 April2 May, 2003, pp. 567-573.

[43] F. Ekhator, O. A. Akinyemiju and S. N. Utulu, "Factors Affecting Giant Sensitive Plant (Mimosa invisa Mart) Seed Germination and Emergence," Nigerian Journal of Weed Science, Vol. 21, 2008, pp. 38-49.

[44] APFISN (Asia-Pacific Forest Invasive Species Network), "Invasive Pest Fact Sheet: Giant Sensitive Plant (Mimosa diplotricha)," 2010.

http://www.fao.org/forestry/13377-1-0.pdf

[45] F. M. Dania Ogbe and J. F. Bamidele, "Incidence and Spread of an Invasive Weed, Mimosa invisa Mart. in Benin City Metropolis, Nigeria,” International Journal Botany, Vol. 2, No. 3, 2006, pp. 336-339. doi:10.3923/ijb .2006.336.339

[46] FAO, "Food and Agricultural Organization of the United Nations,” 2000.

http://apps.fao.org/lim500/nphwrap.pl?production.crops.p rimary

[47] International Institute of Tropical Agriculture, "Cassava in Tropical Africa: A Reference Manual,” Balding \& Mansell, London, 1990, pp. 1-8.

[48] E. R. Terry, E. V. Doku, B. Arene and M. M. Mahungu, "Tropical Root Crops: Production and Uses in Africa, Ibadan, Nigeria,” International Institute of Tropical Agriculture (IITA), Ibadan, 1983, pp. 114-117.

[49] K. V. Sankaran, "Mimosa invisa: A Growing Menace in South India,” Biocontrol News and Information, Vol. 22, 2001, pp. 4-5.

[50] D. S. Wilcove, D. Rothstein, J. Diubow, A. Phillips and E. Losos, "Quantifying Threats to Imperiled Species in the United States,” BioScience, Vol. 48, No. 8, 1998, pp. 607615. doi:10.2307/1313420

[51] C. C. Daehler, "Performance Comparisons of Co-Occurring Native and Alien Invasive Plants: Implications for Conservation and Restoration,” Annual Review of Ecology and Systematics, Vol. 34, 2003, pp. 183-211. doi:10.1146/annurev.ecolsys.34.011802.132403

[52] C. V. Hawkes, "Are Invaders Moving Targets? The Generality and Persistence of Advantages in Size, Reproduction, and Enemy Release in Invasive Plant Species with Time since Introduction,” The American Naturalist, Vol. 170, No. 6, 2007, pp. 832-843. doi:10.1086/522842

[53] S. Ramula, T, M. Knight, J. H. Burns and Y. M. Buckley, "General Guidelines for Invasive Plant Management Based on Comparative Demography of Invasive and Native Plant Populations,” Journal of Applied Ecology, Vol. 45, No. 4, 2008, pp. 1124-1133. doi:10.1111/j.1365-2664.2008.01502.x

[54] M. van Kleunen, E. Weber and M. Fischer, “A Meta- 
Analysis of Trait Differences between Invasive and NonInvasive Plant Species,” Ecology Letters, Vol. 13, No. 2, 2010, pp. 235-245.

doi:10.1111/j.1461-0248.2009.01418.x

[55] A. Ordonez, I. J. Wright and H. Olff, "Functional Differences between Native and Alien Species: A Global-Scale Comparison," Functional Ecology, Vol. 24, 2010, pp. 1353-1361. doi:10.1111/j.1365-2435.2010.01739.x

[56] A. M. Davidson, M. Jennions and A. B. Nicotra, "Do Invasive Species Show Higher Phenotypic Plasticity than Native Species and, If So, Is It Adaptive? A Meta-Analysis,” Ecology Letters, Vol. 14, No. 4, 2011, pp. 419-431. doi:10.1111/j.1461-0248.2011.01596.x

[57] M. I. Galinato, K. Moody and C. M. Piggin, "Upland Rice Weeds of South and Southeast Asia,” International Rice Research Institute, Makati City, 1999.

[58] B. Rerkasem, T. Yoenyama and K. Rerkasem, "Spineless mimosa (Mimosa invisa), a Potential Live Mulch for Corn,” Agricultural Systems Programme, Chiangmai University, Chiang Mai, 1992.

[59] K. Rerkasem, "Farmers Management of Fallow Succession in Thailand," Paper Presented at the International Symposium Managing Biodiversity in Agricultural Ecosystems, Montreal, 2001.

[60] R. Wittenberg and M. J. W. Cock, "Invasive Alien Species: A Toolkit for Best Prevention and Management Practices,” CAB International, Wallingford, 2001. doi:10.1079/9780851995694.0000

[61] J. A. McNeely, "The Great Reshuffling: Human Dimensions of Invasive Alien Species,” IUCN, Gland, Cambridge, 2001.

[62] M. A. Davis, M. K. Chew, R. J. Hobbs, A. E. Lugo, J. J. Ewel, et al., "Don't Judge Species on Their Origins," Nature, Vol. 474, No. 7350, 2011, pp. 153-154. doi:10.1038/474153a

[63] D. Simberloff, J. Alexander, F. Allendorf, J. Aronson, P. M. Antunes, et al., "Non-Natives: 141 Scientists Object," Nature, Vol. 475, No. 7354, 2011, p. 36. doi:10.1038/475036a

[64] A. Alyokhin, "Non-Natives: Put Biodiversity at Risk," Nature, Vol. 475, No. 7354, 2011, p. 36. doi:10.1038/475036b

[65] J. L. Lockwood, M. F. Hoopes and M. P. Marchetti, "Non-Natives: Plusses of Invasion Ecology," Nature, Vol. 475, No. 7354, 2011, p. 36. doi:10.1038/475036c

[66] M. Lerdau and J. D. Wickham, "Non-Natives: Four Risk Factors,” Nature, Vol. 475, No. 7354, 2011, pp. 36-37. doi:10.1038/475036d
[67] B. W. van Wilgen, A. Khan and C. Marais, "Changing Perspectives on Managing Biological Invasions: Insights from South Africa and the Working for Water Programme,” In: D. M. Richardson, Ed., Fifty Years of Invasion Ecology: The Legacy of Charles Elton, WileyBlackwell, Oxford, 2011, pp. 377-393.

[68] S. Selge, A. Fischer and R. van der Wal, "Public and Professional Views on Invasive Non-Native Species: A Qualitative Social Scientific Investigation,” Biological Conservation, Vol. 144, No. 12, 2011, pp. 3089-3097. doi:10.1016/j.biocon.2011.09.014

[69] S. A. Bhagwat, E. Breman, T. Thekaekara, T. F. Thornton and K. J. Willis, "A Battle Lost? Report on Two Centuries of Invasion and Management of Lantana camara L. in Australia, India and South Africa," PLOS ONE, Vol. 7, No. 3, 2012, p. e32407. doi:10.1371/journal.pone.0032407

[70] R. G. Westbrooks, "New Approaches for Early Detection and Rapid Response to Invasive Plants in the United States," Weed Technology, Vol. 18, Suppl. 1, 2004, pp. 1468-1471. doi:10.1614/0890-037X(2004)018[1468:NAFEDA]2.0.C $\underline{\mathrm{O} ; 2}$

[71] B. S. Alabi, A. O. Ayeni, A. A. Agboola and B. A. Majek, "Manual Control of Thorny Mimosa (Mimosa invisa) in Cassava (Manihot esculenta),” Weed Technology, Vol. 18, No. 1, 2004, pp. 77-82. doi:10.1614/0890-037X(2004)018[0077:MCOTMM]2.0. $\mathrm{CO} ; 2$

[72] I. O. Akobundu, "Weed Science in the Tropics: Principles and Practices," John Wiley and Sons, London, 1987.

[73] J. T. Swarbrick, "Weeds of the Pacific Islands," South Pacific Commission, Mounea, 1997.

[74] M. H. Julien, and M. W. Griffiths, "Biological Control of Weeds-A World Catalogue of Agents and Their Target Weeds," 4th Edition, CAB Int., Oxon, 1998.

[75] M. P. Vitelli, C. Garcia, C. J. Lockett, G. M. West and B. W. Willson, "Host Specificity and Biology of the Moth Psigida walkeri (Lepidoptera: Citheroniidae), a Potential Biological Control Agent for Mimosa diplotricha in Australia and the South Pacific,” Biological Control, Vol. 22, No. 22, 2001, pp. 1-8. doi:10.1006/bcon.2001.0947

[76] A. W. Crall, M. Renz, B. J. Panke, G. J. Newman, C. Chapin, J. Graham and C. Bargeron, "Developing CostEffective Early Detection Networks for Regional Invasions,” Biological Invasions, Vol. 14, No. 12, 2012, pp. 2461-2469. doi:10.1007/s10530-012-0256-3 